\title{
KEBIJAKAN APLIKASI QLUE DALAM PEMBANGUNAN DAERAH DI PROPINSI DAERAH KHUSUS IBUKOTA JAKARTA (STUDI DESKRIPTIF DI KELURAHAN TENGAH, KECAMATAN KRAMAT JATI, JAKARTA TIMUR)
}

\author{
Oleh: Reza Rafiansa*, Tjipto Sumadi*, Mohammad Maiwan
}

\begin{abstract}
This research is encouraged by the rejection of Jakarta Government Policy which requires the Head of Neighborhood Association (RT) and Community Association (RW) to use Qlue Application in helping the government to overcome the City problem. Research method used is descriptive method within qualitative approach. The informants in this research are Heads of RT and RW. Key Informants are Head of Administrative Village, Governmental Peace of Order Section, and Economic Development Section at Kelurahan Tengah. The results of the research show that Application of Qlue Application Policy has been running well. This is seen from the fulfillment of Evaluation Indicators of the effectiveness, efficiency, adequacy and responsiveness. While the Impact of Development is caused by the Report of City Problems that encourages the creation of Regional Development which is seen from the improvement of service, the development, empowerment, and the participation of citizens in following up the Qlue report.
\end{abstract}

Keywords : Public Policy, Qlue Application, Regional Development

\begin{abstract}
ABSTRAK
Penelitian ini dilatarbelakangi oleh penolakan terhadap Kebijakan Pemerintah Jakarta yang mengharuskan Ketua (RT) Rukun Tetangga dan Rukun Warga (RW) untuk menggunakan Aplikasi Qlue dalam membantu pemerintah mengatasi masalah Kota. Metode penelitian yang digunakan adalah metode deskriptif dengan pendekatan kualitatif. Informan dalam penelitian ini adalah Kepala RT dan RW. Informan Kunci adalah Lurah, Seksi Ketertiban Pemerintahan, dan Bagian Pengembangan Ekonomi di Kelurahan Tengah. Hasil penelitian menunjukkan bahwa Penerapan Kebijakan Aplikasi Qlue telah berjalan dengan baik. Hal ini terlihat dari pemenuhan Indikator Evaluasi terhadap efektifitas, efisiensi, kecukupan dan daya tanggap. Sedangkan Dampak Pembangunan disebabkan oleh Laporan Masalah Kota yang mendorong terciptanya Pembangunan Daerah yang dilihat dari peningkatan pelayanan,
\end{abstract}

* Program Studi Pendidikan Pancasila dan Kewarganegaraan Fakultas Ilmu Sosial Universitas Negeri Jakarta. Email: rrafiansa@gmail.com

* Dosen Program Studi Pendidikan Pancasila dan Kewarganegaraan Fakultas Ilmu Sosial Universitas Negeri Jakarta.

- Dosen Program Studi Pendidikan Pancasila dan Kewarganegaraan Fakultas Ilmu Sosial Universitas Negeri Jakarta. Email:maiwan@unj.ac.id. 
pengembangan, pemberdayaan, dan partisipasi warga dalam menindaklanjuti laporan Qlue.

Kata Kunci : Kebijakan Publik, Aplikasi Qlue, Pembangunan Daerah

\section{Pendahuluan}

DKI Jakarta sebagai Ibu kota memiliki permasalahan kota yang sangat kompleks yang membutuhkan penanganan oleh pemerintah dengan cepat dan tepat. Permasalahan kota yang sering kali terjadi di DKI Jakarta diantaranya seperti masalah kemacetan, banjir, parkir liar, sampah, sarana prasarana umum serta pelanggaran lainnya. Dalam hal ini yaitu Pemerintah Provinsi DKI Jakarta mengeluarkan sebuah alternatif kebijakan dengan memanfaatkan teknologi informasi dan komunikasi dalam menyelanggarakan pemerintahan dengan cara membuat Jakarta Smart City (JSC) untuk membantu mengatasi permasalahan kota dengan cepat dan tepat. Jakarta Smart City ini sebagai wadah utama untuk menampung laporan warga serta dalam penerapannya sangat bergantung sekali pada empat kanal pengaduan warga yang disediakan oleh pemerintah diantaranya yaitu melalui sosial media resmi Pemerintah DKI Jakarta, call centre, open house balai warga $\mathrm{di}$ kecamatan serta melalui Aplikasi Qlue.
Berdasarkan empat kanal pengaduan warga tersebut terdapat satu kanal pengaduan warga yang menuai sebuah permasalahan didalam penerapannya yaitu didalam kanal pengaduan warga melalui Aplikasi Qlue. Aplikasi Qlue merupakan sebuah aplikasi pelaporan warga untuk menyampaikan seluruh keluhan dan permasalahan warga yang ada di DKI Jakarta kepada pemerintah secara realtime. Aplikasi Qlue merupakan Aplikasi milik pihak swasta yang kemudian bekerjasama dengan Pemerintah dalam mengembangkan konsep Smart City di DKI Jakarta. Bentuk kerjasama yang dilakukan yaitu dengan menerapkan Aplikasi Qlue ini sebagai laporan warga yang digunakan oleh Ketua RT dan RW sebagai sebuah media untuk menyampaikan kondisi, informasi, peristiwa yang ada dilingkungannya masing masing. Penerapan Aplikasi Qlue ini merupakan sebuah Alternatif kebijakan yang diambil oleh pemerintah dalam mengatasi permasalahan kota di DKI Jakarta yang sangat kompleks dengan 
melibatkan partisipasi warga yang dalam hal ini yaitu Ketua RT dan RW untuk melaporkan kondisi lingkungannya kepada pemerintah Melalui Aplikasi Qlue.

Penerapan Aplikasi Qlue ini diatur dalam Surat Keputusan Gubernur Nomor 903 DKI Jakarta Tahun 2016 serta dalam Peraturan Gubernur Nomor 7 Tahun 2017. Regulasi ini merupakan sebuah produk kebijakan yang diambil pemerintah untuk mengatasi permasalahan kota dengan cepat dan tepat. Oleh karena itu, maka Penelitian ini berupaya untuk mengetahui bagaimana Penerapan Kebijakan Aplikasi Qlue serta dampak yang dihasilkan dari kebijakan terhadap Pembangunan Daerah di DKI Jakarta. Adapun kegunaan penelitian ini untuk melihat sejauh mana keberhasilan penerapan kebijakan dalam mengatasi permasalahan kota serta untuk melakukan evaluasi terhadap penerapan Kebijakan yang telah diberlakukan.

$$
\text { Pemerintah mengeluarkan }
$$

kebijakan Penerapan Aplikasi Qlue sebagai sebuah tindakan yang dilakukan oleh pemerintah dalam mengatasi permasalahan kota. Seperti yang diungkapkan oleh Thomas R. Dye bahwa kebijakan publik adalah pilihan- pilihan apapun yang diambil oleh pemerintah, baik untuk melakukan sesuatu maupun untuk tidak melakukan sesuatu whatever government choose to do or not to do. (Budi winarno, 2009:17) Pemerintah memilih atau tidak memilih melakukan pun dimaknai sebagai Kebijakan Publik. Selanjutnya untuk melihat sejuah mana penerapan Kebijakan yang dipilih oleh pemerintah berhasil diterapkan maka perlunya mengetahui bagaimana kebijakan ini diterapkan dengan terlebih dahulu melihat faktor faktor yang memengaruhi Kebijakan.

Menurut George C. Edwars III faktor-faktor yang mempengaruhi implementasi kebijakan diantaranya terdapat empat faktor atau variabel krusial dalam implementasi kebijakan public yang terdiri atas variabel-variabel 1) komunikasi; 2) sumber-sumber; 3) Disposisi atau tingkah laku-tingkah laku, dan 4) struktur birokrasi. (Budi winarno, 2009:156) 1) Komunikasi, Menurut Edwards persyaratan pertama bagi implementasi kebijakan adalah bahwa mereka yang melaksanakan keputusan harus mengetahui apa yang harus mereka lakukan. Tiga aspek atau faktor penting dalam proses komunikasi kebijakan yakni transmisi, konsistesi, 
dan kejelasan (clarity). Apabila tujuan dan sasaran suatu kebijakan tidak jelas atau bahkan tidak diketahui sama sekali oleh kelompok sasaran, maka kemungkinan akan terjadi resistensi darikelompok sasaran. 2) Sumber daya, Berkenaan dengan ketersediaan sumber daya pendukung. Perintah-perintah implementasi mungkin diteruskan secara cermat dan sudah dikomunikasikan secara jelas dan konsisten, tetapi jika para pelaksana kekurangan sumber-sumber yang diperlukan unutk melaksanakan kebijakan-kebijakan, maka implementasi cenderung tidak efektif. Sumber-sumber yang penting meliputi : Staf, wewenang, dan fasilitas-fasilitas serta sumber daya finansial. 3) Disposisi, Disposisi adalah watak dan karakteristik yang dimiliki implementor, seperti kesediaan, komitmen, kejujuran, sifat demokratis. Apabila implementor memiliki disposisi yang baik, maka dia akan dapat menjalankan kebijakan dengan baik seperti apa yang diinginkan oleh pembuat kebijakan.

Penerapan Kebijakan Aplikasi Qlue selanjutnya dianalisa menggunakan Evaluasi Kebijakan untuk menilai keberhasilan penerapan kebijakan. Menurut Muhadjir dalam buku yang ditulisan oleh Widodo mengemukakan bahwa Evaluasi kebijakan publik merupakan suatu proses untuk menilai seberapa jauh suatu kebijakan publik dapat membuahkan hasil, yaitu dengan membandingkan antara hasil yang diperoleh dengan tujuan dan atau target kebijakan publik yang ditentukan. (Joko widodo, 2008:112) Lebih lanjut Evaluasi Kebijakan menurut William N. Dunn mengemukakan beberapa hal mengenai indikator kriteria yang diperlukan dalam melakukan proses evaluasi kebijakan publik, yaitu: 1) Efektivitas 2) Efisiensi 3) Kecukupan 4) Perataan 5) Responsivitas 6) Ketepatan. ( William N. Dunn, 2003:158)

Indikator kriteria yang pertama yaitu, 1) Efektivitas, Berkenaan dengan apakah suatu alternatif mencapai hasil (akibat) yang diharapkan, atau mencapai tujuan dari diadakannya tindakan. 2) Efesiensi, Efisiensi yang merupakan sinonim dari rasionalitas ekonomi adalah merupakan hubungan antara efektifitas dan usaha, yang terakhir umumnya diukur dari ongkos moneter. 3) Kecukupan, Kriteria kecukupan menekankan pada kuatnya hubungan antara alternatif kebijakan dan hasil yang diharapkan. 4) Perataan, Erat 
berhubungan dengan rasionalitas legal dan sosial dan menunjuk pada distribusi akibat dan usaha antara kelompokkelompok yang berbeda dalam masyarakat. 5) Responsivitas, berkenaan dengan seberapa jauh suatu kebijakan dapat memuaskan kebutuhan, preferensi, atau nilai kelompok-kelompok masyarakat tertentu. 6) Ketepatan, berhubungan dengan rasionalitas, substantif, karena pertanyaan tentang ketepatan kebijakan tidak berkenaan dengan satuan kriteria individu tetapi dua atau lebih kriteria secara bersama-sama.

\section{Penerapan Kebijakan Aplikasi}

Qlue erat kaitannya dengan usaha yang dilakukan pemerintah dalam mengatasi Permasalahan Kota di DKI Jakarta. Usaha usaha yang dilakukan akan berdampak pada Pembangunan Daerah. Oleh karena itu untuk melihat dampak pembangunan daerah yang terjadi akibat diterapkannya kebijakan Aplikasi Qlue maka selanjutnya akan dianalisa menggunakan konsep pembangunan Daerah. Pembangunan merupakan suatu proses perubahan di berbagai aspek kehidupan yang dilakukan secara sengaja berdasarkan suatu rencana tertentu. baik oleh pemerintah yang menjadi pelopor pembangunan maupun masyarakat itu sendiri. (Soerjono Soekanto, 2015 :358)

Lebih lanjut Siagian $\mathrm{P}$ sondang menjelaskan bahwa Pembangunan Daerah merupakan keseluruhan proses rangkaian usaha-usaha yang dilakukan dalam lingkungan dengan tujuan untuk meningkatkan taraf hidup masyarakat serta memperbesar kesejahteraan. Dalam pembangunan Daerah ada tiga unsur utama yang perlu diperhatikan bagi keberhasilan Pembangunan Daerah yaitu, Keikutsertaan masyarakat dalam pembangunan, Timbulnya gagasangagasan baru didalam masyarakat mengenai kehidupan mereka dimasa mendatang serta diterapkan teknologi yang tepat guna dan padat karya. (Siagian P. Sondang, 2003 : 108) Dalam Penerapan Kebijakan dapat dilihat apakah terdapatnya sebuah pembangunan dengan cara menganalisa melalui konsep pembangunan Daerah yang disampaikan oleh Rasyid Ryass bahwa Pelaksanaan Pembangunan yang dilaksanakan pemerintah selalu berpatokan pada tugas pokok dan fungsi yang diatur oleh peraturan yang ditentukan dan pelaksanaan tugas pokok dan fungsinya tergantung pihak pemimpinnya sendiri. Dalam hal ini kegiatan yang harus dilaksanakan atau 
dijalankan terdapat tiga fungsi yang hakiki yaitu : 1) pelayanan (service), 2) pemberdayaan (empowerment), dan 3) pembangunan (development). (Rasyid Ryass, $2000: 43$ )

\section{Metodologi Penelitian}

Metode penelitian yang digunakan dalam penelitian ini adalah penelitian deskriptif dengan pendekatan kualitatif. Metode Penelitian Deskriptif adalah merupakan suatu metode yang banyak dipergunakan dan dikembangkan dalam penelitian ilmuilmu sosial. (Sugiyono, 2013 : 285) Penelitian yang bersifat deskriptif dimaksudkan untuk mendeskripsikan suatu situasi atau area populasi tertentu yang bersifat faktual secara sistematis, menyeluruh, luas, mendalam dan akurat yang dirancang untuk memperoleh informasi tentang suatu gejala pada saat penelitian dilakukan. (Sugiyono, 2013 : 289)

Selanjutnya, sumber data dalam penelitian ini terdiri dari sumber data premier dan sumber data sekunder. Adapun data primer yaitu didapatkan dari informan utama dalam penelitian yaitu pelaksana Kebijakan Aplikasi Qlue yaitu Ketua RT dan Ketua RW. Informan kunci dalam penelitian ini yaitu Lurah, Kepala seksi pemerintaha, ketentraman dan ketertiban serta kepala seksi ekonomi pembangunan dan lingkungan hidup Kelurahan Tengah Kramat Jati Jakarta Timur. Data sekunder adalah sumber yang tidak langsung memberikan data kepada pengumpul data. contohnya data yang berupa dokumentasi, yaitu foto-foto yang peneliti hasilkan sendiri dengan kamera terkait dengan proses wawancara dengan Ketua RT dan RW, Data Laporan Qlue Kelurahan Tengah, Catatan hasil wawancara yang diperoleh peneliti saat melakukan wawancara dengan informan penelitian, serta data-data lain yang dijadikan bahan tambahan untuk mendapatkan data objektif penelitian.

Sumber data diatas dikumpulkan melalui teknik pengumpulan data yang diantaranya melalui Observasi, wawancara serta dengan studi dokumentasi. 1) Observasi, dilakukan dengan cara mengumpulkan data dengan mengamati keadaan wajar tanpa usaha yang disengaja untuk memengaruhi, mengatur, ataupun memanipulasinya. (Basrowi suwandi, 2008 : 93) 2) Wawancara, dilakukan untuk memperoleh data dan informasi secara mendalam, dari sejumlah informan 
utama dan informan kunci untuk mendapatkan informasi secara jelas. 3) Studi dokumentasi, dilakukan untuk memperoleh data penunjang penelitian dalam bentuk foto pada setiap dilakukannya observasi lapangan dan wawancara, tulisan melakukan pencatatan lapangan dan berkas tertulis di Kelurahan Tengah , maupun rekaman suara pada saat melakukan wawancara sebagai lampiran hasil penelitian.

Tahapan selanjutnya setelah seluruh data terkumpul maka dilakukan kaliberasi keabsahan data dengan member check, audit trial, triangulasi serta mengkonfirmasi data dengan expert opinion. 1) Member check, merupakan proses pengecekan data yang telah diperoleh peneliti kepada pemberi data. Tujuannya adalah untuk mengetahui kesesuaian antara data di lapangan dengan data yang diperoleh dari informan. 2) Audit Trial, proses konfirmasi data kepada pihak yang memiliki otoritas lebih tinggi dari sumber pertama di tempat penelitian. Tujuannya adalah agar data yang didapat bisa dipercaya atau tidak. 3) Triangulasi, teknik pengumpulan data yang bersifat menggabungkan dari berbagai teknik pengumpulan data yang telah ada. Data yang didapatkan dari hasil observasi kemudian dicek kembali dengan data dari hasil observasi, wawancara dan juga dari hasil studi dokumenter. 4) Expert Opinion, merupakan proses konfirmasi kepada ahli. maka data dari proses penelitian lebih dipercaya atau teruji kredibilitasnya dan data yang telah ditemukan.

Setelah seluruh tahapan data selesai melalui proses kaliberasi keabsahan data maka selanjutnya dilakukan proses analisis data. Analisis data dilakukan dengan cara diantaranya sebagai berikut, 1) Reduksi data, proses pemilihan, pemutusan perhatian pada penyederhanaan, pengabstrakan, dan transformasi data "kasar" yang muncul dari catatan-catatan tertulis dilapangan.

2) Penyajian data, Data yang telah dikumpulkan, dipetakan sesuai kategori, sehingga menghasilkan pengelompokkan berdasarkan sistematika yang telah dirancang. Sajian data ini terus mengacu pada fokus permasalahan dalam bentuk matriks,tabel, flow chart serta bagan. 3) Membuat kesimpulan, Setelah semua data terkumpul, baik dari studi dokumen, observasi, ataupun wawancara yang tersususn secara sistematis, maka data 
tersebut diolah dan dianalisis. Sehingga

penarikan kesimpulan dalam penelitian

ini didasari oleh data-data yang telah

diolah. 


\section{Hasil dan Pembahasan}

1. Penerapan Kebijakan Aplikasi Qlue di Kelurahan Tengah

Matriks Penerapan Kebijakan Qlue

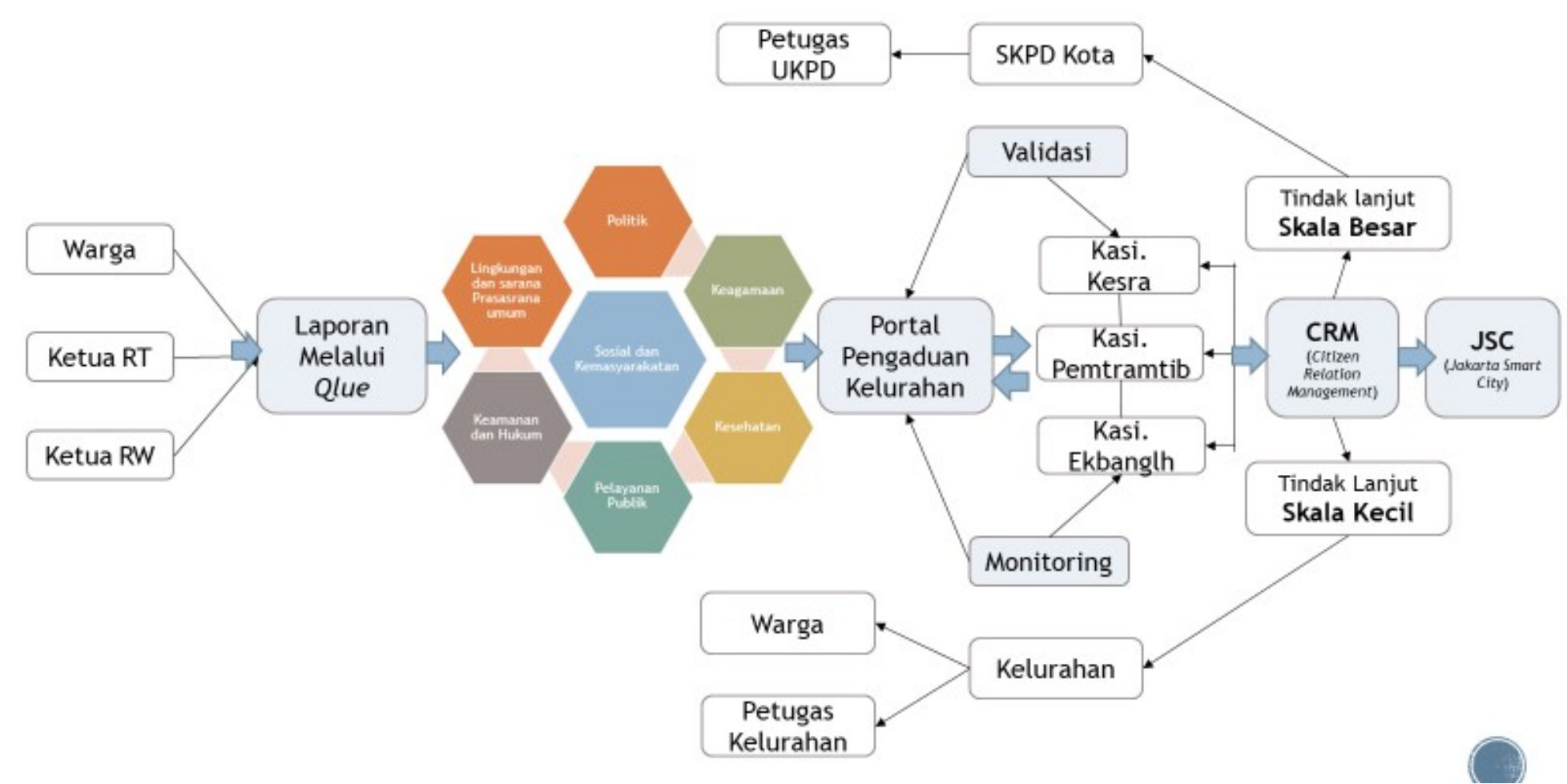


Penerapan Kebijakan Aplikasi
Qlue dilakukan oleh pelaksana Kebijakan yaitu Ketua RT dan Ketua RW. Kebijakan tersebut diatur dalam Keputusan Gubernur DKI Jakarta Nomor 903 Tahun 2016 bahwa ketua RT dan Ketua RW wajib melaporkan kondisi lingkungan sehari tiga kali melalui Aplikasi Qlue. Adapun laporan yang dikirimkan diantaranya meliputi beberapa aspek didalam pembangunan daerah seperti, aspek sosial, politik, hukum, lingkungan, sarana prasrana, kesehatan, keamanan, ketertiban, kemasyarakatan, pelayanan publik dan agama.

\section{a) Aspek Sosial}

Adapun laporan mengenai aspek sosial diantaranya laporan masalah Pengamen Jalanan, Pengemis Jalanan, Sumbangan Liar, Bunuh diri dengan gantung diri, Disintegrasi sosial pemilukada, Pelatihan Bogasari, Kegiatan Pemberdayaan ibu dan anak

\section{b) Lingkungan dan sarana}

prasarana umum

Laporan pada aspek ini diantaranya laporan mengenai masalah pada Jalan Rusak , Lampu PJU Padam, Longsor kali, Got tersumbat, Kabel listrik membahayakan, Trafict Light Tertutup
Pohon, Pohon Tumbang, Jembatan roboh, Pintu Air tersumbat sampah, Sampah, Banjir , Pembuatan Lubang Biopori, Reboisasasi Bantaran Kalibaru, Perbaikan Tempat Penampungan Sampah Sementara.

c) Politik

Laporan pada aspek ini diantaranya meliputi Kegiatan Kampanye Sara, Spanduk Kampanye Sara, Sosialisasi Pengawas Pemilukada, Bimbingan Teknis Pemilukada, Politik Uang, Politik Sembako, Provokasi Kampanye.

d) Kemasyarakatan

Meliputi kegiatan laporan Rembug Warga, Musrenbang RW, Karang Tarunan, Kerja bakti, Senam, PKBM Sekolah Kejar Paket, Dharmawisata RT RW, Silaturahmi Tokoh Masyarakat.

e) Kesehatan

Meliputi laporan mengenai kegiatan Jumantik, Laporan DBD, Posyandu balita, Posyandu Lansia, Layanan Ketuk Pintu, Sosialisasi Difteri, Fooging.

f) Keamanan dan Hukum

Tawuran, Pencurian Kendaraan, Pengedar dan Pengguna Narkoba, Penipuan Modus Hipnotis, Penipuan Modus PLN, Antisipasi Tawuran, Patroli 
3 Pilar ( Babinsa, Bimas, Pokdar), Pembuatan Portal, Pembuatan Gerbang, Pencegahan melalui FKDM, Ronda malam minggu, Parkir liar, Pedagang Kaki Lima, Patroli Satpol PP kelurahan, Bangunan di bantaran kali.

g) Pelayanan Publik

Laporan mengenai Penelantaran Pasien Puskesmas, Pelayananan Pembuatan EKTP yang lama prosesnya, Ketidaknyamanan warga karena parkiran menghalangi akses masuk kelurahan, Sosialisasi Peningkatan Pelayanan Publik kepada RT RW di Kelurahan Tengah.

h) Agama

Laporan mengenai Kegiatan Maulid Nabi, Kegiatan Hari Raya Islam, Kegiatan Hari Raya Natal, Pengajian Bulanan, Tabligh Akbar, Kenaikan Isa Almasih, Renovasi Tempat Ibadah.

\section{Seluruh laporan yang disampaikan melalui Aplikasi Qlue yang meliputi pembangunan daerah tersebut masuk kedalam portal pengaduan warga di Kelurahan. Setelah seluruh laporan terkumpul tahapan selanjutnya yaitu proses validasi dan monitoring laporan yang dilakukan oleh Kelurahan sesuai dengan bagian}

bidangnya masing masing. Pihak yang berkewajiban untuk melakukan validasi dan monitoring di Kelurahan yaitu, Kepala seksi bidang pemerintahan, kententraman, ketertiban, Kepala seksi bidang ekonomi pembangunan dan lingkungan hidup, serta Kepala seksi bidang kesehatan dan kesejahteraan. Laporan yang telah melewati tahapan validasi dan monitoring oleh pihak kelurahan akan ditindaklanjuti berdasarkan skala permasalahan. Pengelompokan dan penentuan skala digolongkan berdasarkan skala besar dan kecilnya permasalahan.

Permasalahan berskala kecil merupakan tanggung jawab kelurahan untuk menindaklanjuti penangannya, semenatara laporan berskala besar merupakan kewajiban Satuan Kerja Perangkat Daerah di Tingkat Kota yang berhak menindaklanjuti sesuai dengan permasalahannya. Pengkoordinasian tindaklanjut ini melalui Aplikasi Citizen Relation Mechanism (CRM) yaitu Aplikasi yang menghubungkan laporan Qlue kepada dinas dinas terkait dalam rangka penanganan permasalahan kota dengan cepat dan tepat dan selanjutnya seluruh permasalahan akan diteruskan masuk kedalam kanal utama penampungan laporan warga berbasis 
teknologi yang akan mucul didalam

Jakarta Smart City milik Pemerintah

DKI Jakarta yang langsung terhubung kepada Gubernur DKI Jakarta sehingga

dapat memantau kinerja aparat

pemerintah dalam menindaklanjuti

laporan warga 
2. Dampak Kebijakan Aplikasi Qlue dalam Pembangunan Daerah.

Matriks Dampak Pembangunan Daerah
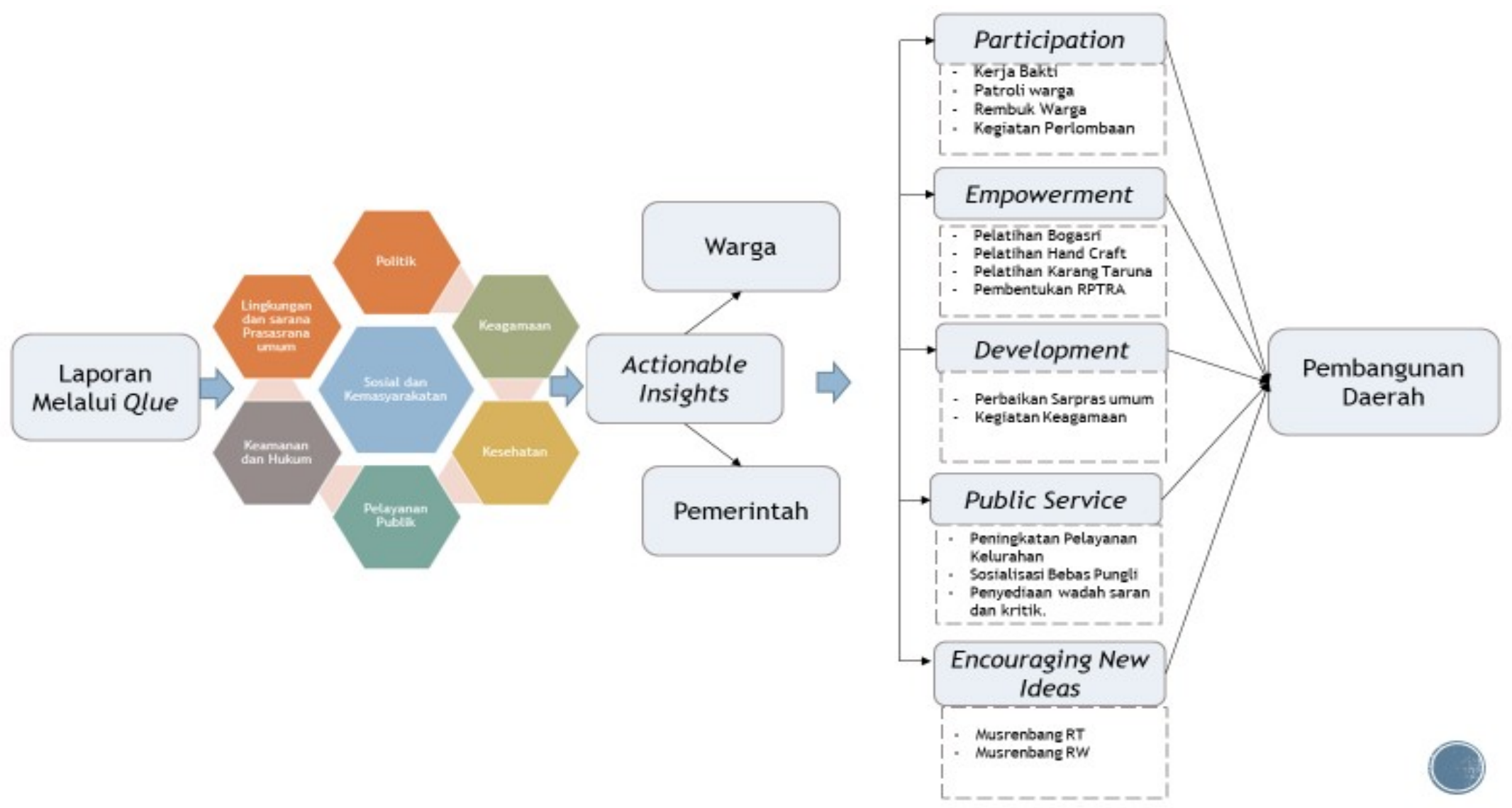
Dampak penerapan Kebijakan Aplikasi Qlue dalam Pembangunan Daerah dapat terlihat bahwa laporan Qlue yang disampaikan oleh Ketua RT, Ketua RW dan Warga meliputi beberapa Aspek didalam pembangunan daerah seperti aspek sosial, politik, hukum, lingkungan, sarana prasrana, kesehatan, keamanan, ketertiban, kemasyarakatan, pelayanan publik dan agama menjadi sebuah Actionable Insights, yaitu menjadi sebuah wawasan yang dapat ditindaklanjuti oleh warga serta pemerintah. Wawasan tersebut didapatkan dari laporan Qlue sehingga warga dan pemerintah mengetahui permasalahan yang terjadi dilingkungannya sehingga secara bersinergis mendorong terciptanya faktor fator pembangunan daerah yang diantaranya sebagai berikut, Partispasi (Participation), Pemberdayaan (empowerment), Pembangunan (Development), Pelayanan Publik (Public Service) serta Timbulnya Gagasan Baru (Encouraging New Ideas).

\section{Mendorong Partispasi (Participation)}

$$
\text { Partisipasi Keikusertaan }
$$

Masyarakat dalam Penerapan Kebijakan Aplikasi Qlue terhadap Pembangunan Pembangunan Daerah dihasilkan dari laporan permasalahan yang dikirimkan warga dan Ketua RT RWKepada pemerintah serta upaya upaya yang dilakukan masyarakat dalam memperbaiki permasalahan yang terjadi dilingkungan. Misalnya pada laporan Qlue terkait laporan runtuhnya tanggul kali baru di RW 01, warga disekitar melakukan penanganan darurat sebagai keikusertaannya dalam mengatasi kerusakan runtuhnya tanggul dilingkungan wilayah RW 01.

2. Dilakukannya Pemberdayaan (empowerment)

Upaya dalam mengatasi permasalahan sosial, ekonomi dan lingkungan Kelurahan Tengah telah melakukan beberapa Pemberdayaan dengan mengoptimalkan fungsi RPTRA (Ruang Publik Terpadu Ramah Anak) dan melakukan pemebedayaan Ibu dan anak melaui Kader PKK. Seperti diadakannya kegiatan Pelatihan Bogasari, Posko konseling keluaraga di RPTRA, Kegiatan pemberdayaan daur ulang sampah serta kegiatan pendampingan UMKM untuk memberikan perbedayaan kepada warga di kelurahan Tengah.

3. Menggerakkan Pembangunan 
(Development)

Upaya pembangunan yang bersifat fisik yang dilakukan dalam menindaklanjuti laporan Qlue yaitu pada pembangunan Skala kecil. Misalnya dalam menindaklanjuti permasalahan jalan berlubang jika kerusakan jalan dibawah 5 meter Kelurahan akan menangani secara langsung, tetapi jika skala kerusakan besar lebih dari 5 meter kelurahan akan berkoordinasi kepada dinas terkait untuk mengatasi permasalahan tersebut. Upaya pembangunan yang dilakukan Kelurahan lebih kepada perbaikan yang sifatnya penanganan dini untuk mencegah dampak lain yang timbul dari adanya permasalahan.

\section{Perbaikan Pelayanan Publik (Public} Service)

Upaya perbaikan
pelayanan publik yang dilakukan
dengan Kelurahan Tengah telah
melakukan sosialisasi pelayanan
publik kepada diantaranya
kepada Petugas pelayanan
terpadu Kelurahan, Ketua RT
RW, Petugas RPTRA, Petugas
PPSU, Petugas Kesehatan
Puskesmas Kelurahan, Kader
Jumantik, Kader PKK, FKDM,

LMK serta lembaga lain yang strukturnya sebagai mitra Kerja Kelurahan seperti lembaga Pelayanan Kesehatan, Layanan Pendidikan, Kepolisian Sektor Kramat Jati dan lainnya untuk meningkatkan Pelayanan Publik di Kelurahan Tengah.

5. Mendorong Timbulnya Gagasan Baru (Encouraging New Ideas)

Adanya laporan Qlue membuat kelompok warga membuat gagasan gagasan baru untuk mencari cara dengan mengelurkan gagasan maupun ide ide sebagai upaya yang akan dilakukan untuk mengatasi permasalahan melalui kegiatan rembug warga dan kegiatan musyawarah rencana pembangunan.

$$
\text { Untuk memperjelas }
$$

Dampak Penerapan Kebijakan Qlue dalam Pembangunan Daerah berikut ini merupakan hasil tindaklanjut laporan Qlue yang dilakukan Kelurahan Tengah dalam mengatasi permasalahan kota yang 
dilaporkan oleh Ketua RT, Ketua

RW dan Warga melalui Aplikasi

Qlue di Kelurahan Tengah

Kramat Jati Jakarta Timur. 
Tabel

Penerapan Kebijakan Qlue dalam Pembangunan Daerah di Kelurahan Tengah

\begin{tabular}{|c|c|c|c|}
\hline Laporan Qlue & Permasalahan Kota & Tindak lanjut & $\begin{array}{c}\text { Dampak Pembangunan } \\
\text { Daerah }\end{array}$ \\
\hline RW 01 & $\begin{array}{l}\text { Robohnya tanggul Kali } \\
\text { baru }\end{array}$ & Dinas Tata Air & $\begin{array}{l}\text { Perbaikan Tanggul skala } \\
\text { besar }\end{array}$ \\
\hline RW 01 RT 002 & $\begin{array}{l}\text { Robohnya Jembatan } \\
\text { Kali baru }\end{array}$ & $\begin{array}{l}\text { Dinas Pekerjaan } \\
\text { Umum }\end{array}$ & Renovasi Jembatan Kali baru \\
\hline RW 02 RT 004 & $\begin{array}{l}\text { Jalan Raya Inpres } \\
\text { berlubang }\end{array}$ & $\begin{array}{l}\text { PPSU Kelurahan } \\
\text { Tengah }\end{array}$ & Penambalan Jalan berlubang \\
\hline RW 03 & Parkir liar & $\begin{array}{l}\text { Dinas Perhubungan } \\
\text { dan Satpol PP } \\
\text { Kelurahan Tengah }\end{array}$ & $\begin{array}{l}\text { Derek kendaraan serta } \\
\text { pengempesan ban kendaraan }\end{array}$ \\
\hline RW 04 & Kriminal pencurian & Warga dan Kelurahan & Pembuatan Portal \\
\hline RW 004 RW 08 & $\begin{array}{l}\text { TPA Sampah } \\
\text { menumpuk }\end{array}$ & $\begin{array}{l}\text { PPSU dan Dinas } \\
\text { Kebersihan }\end{array}$ & $\begin{array}{l}\text { Permbersihan sampah dan } \\
\text { Pengangkutan sampah }\end{array}$ \\
\hline RW 07 & Tawuran warga & Warga dan Kelurahan & $\begin{array}{l}\text { Patroli } 3 \text { Pilar Bimas Babinsa } \\
\text { dan warga, Pemberdayaan } \\
\text { dan pemanfaatan RPTRA }\end{array}$ \\
\hline RW 07 RT 004 & PKL liar & Satpol PP Kelurahan & $\begin{array}{l}\text { Pemasangan larangan Perda } \\
\text { ketertiban, Penanaman } \\
\text { Pohon dilahan bantaran kali }\end{array}$ \\
\hline RW 08 RT 001 & $\begin{array}{l}\text { Pencemaran limbah } \\
\text { percetakan di kali baru }\end{array}$ & $\begin{array}{l}\text { Dinas Tata Air dan } \\
\text { Satpol PP Kelurahan }\end{array}$ & $\begin{array}{l}\text { Penutupan saluran air } \\
\text { percetakan }\end{array}$ \\
\hline
\end{tabular}

Sumber : Dokumentasi Laporan Qlue Kelurahan Tengah 


\section{Penutup}

Penerapan Kebijakan Aplikasi Qlue di wilayah Kelurahan Tengah sudah berjalan baik. Hal ini dilihat berdasarkan Indikator Evaluasi Kebijakan bahwa dalam Penerapan Kebijakan Aplikasi Qlue sudah berhasil mencapai Indikator Evaluasi Kebijakan yaitu efektifitas, efisiensi, kecukupan, dan responsifitas. Selanjutnya Indikator yang belum berhasil tercapai diantaranya yaitu Indikator ketepatan dan perataan Kebijakan. Adapun yang menyebabkan belum berhasil tercapainya Indikator perataan karena kurangnya sosialisasi, terdapatnya hambatan sumber daya dan tidak berlakunya sanksi, serta pada Indikator ketepatan Pelaksana Kebijakan. Penerapan Kebijakan Aplikasi Qlue memberikan Dampak terhadap Pembangun Daerah yang disebabkan oleh Laporan Permasalahan kota yang dilaporkan melalui Aplikasi Qlue kepada Pemerintah. Laporan Qlue mendorong terciptanya Pembangunan Daerah.

Hal ini dilihat dari Upaya tindaklanjut dalam mengatasi permasalahan kota yang dilakukan secara sinergis antara pemerintah bersama warga yang mendorong partisipasi (Participation) warga, dilakukanya Perbaikan dalam pelayanan (Service), Perbaikan Pembangunan fisik (Development) yang dilakukan pemerintah dan warga, serta dilakukannya Pembangunan Non fisik melalui Pemberdayaan (Empowerment) baik yang dilakukan oleh Kelurahan maupun inisiatif warga di Kelurahan Tengah dalam menindaklanjuti laporan Permasalahan Kota yang dikirimkan melalui Aplikasi Qlue.

Selanjutnya Implikasi yang ditumbulkan bahwa Berdasarkan hasil temuan bahwa Penerapan Kebijakan Aplikasi Qlue memberikan Dampak terhadap Pembangunan Daerah. Oleh Karena itu, Jika Kebijakan ini direvisi oleh pemerintah dengan mempertimbangkan seluruh masukan dan saran yang disampaikan oleh Ketua RT dan RW mengenai perbaikan isi maupun mekanisme di dalam penerapannya oleh Pemerintah dengan melibatkan warga, Ketua RT RW, serta lembaga kemasyarakatan. Maka dalam penerapannya Kebijakan ini akan mendapatkan penerimaan yang lebih baik, perataan yang lebih luas serta memberikan dampak yang lebih besar terhadap Pembangunan Daerah di DKI Jakarta. 
Adapun Saran yang dapat diberikan yang pertama bagi pemerintah, Seharuasnya dilakukan uji coba kebijakan terlebih dahulu untuk melihat respon penerimaan kebijakan, dilakukannya Sosiliasasi Kebijakan Penerapan Aplikasi Qlue lebih dioptimalkan secara berkala tidak hanya dilakukan satu kali untuk mencegah kesalahpahaman penafsiran isi kebijakan yang memicu terjadinya penolakan, Perlunya merevisi kebijakan dengan memuat ketentuan mekanisme yang lebih jelas misalnya dengan memuat mengenai kriteria laporan apa saja yang dapat dilaporkan melalui Aplikasi Qlue.

Serta saran yang kedua yaitu bagi pelaksana Kebijakan, Seharusnya sebelum menerapkan Pelaksana Kebijakan mengetahui terlebih dahulu substansi isi kebijakan untuk mengurangi resistensi, laporan yang dikirimkan melalui Aplikasi Qlue seharusnya melihat kondisi secara nyata dilapangan untuk mencegah adanya laporan fiktif, perlunya menggerakan swadaya masyarakat lebih aktif sehingga tidak hanya mengandalkan dari sisi pemerintah dalam mengatasi permasalahan kota yang berada dilingkungannya masing masing. Selain itu perlunya komunikasi yang baik dilakukan tidak hanya melalui Aplikasi untuk menciptakan sinergis yang baik antara warga dan pemerintah.

\section{Daftar Pustaka}

Basrowi,Suwandi.(2008). Memahami

Penelitian Kualitatif, Jakarta: Rineka Cipta.

Dunn, William N.(2003)..Analisis

Kebijakan Publik, Yogyakarta: Gajah

Mada University Press.

Dunn, William N.(2010). Pengantar

Analisis Kebijakan Publik, Yogyakarta:

Pustaka Pelajar.

Ryaas, Rasyid.(2000). Otonomi Daerah

Dalam Kesatuan, Yogyakarta: Pustaka

Pelajar.

Ryaas, Rasyid.(2000). Makna

Pemerintahan, Tinjauan Dari Segi

Etika Dan Kepemimpinan, Jakarta :

Mutiara Sumber Widya.

Siagian, Sondang P. (1994).

Administrasi Pembangunan, Jakarta: CV. Haji Masagung.

Siagian, Sondang P. (2003). Manajemen Sumber Daya Manusia, Jakarta : Bumi Aksara

Soekanto, Soerjono.(2015). Sosiologi Suatu Pengantar, Jakarta : PT. Raja Grafindo Persada.

Subarsono, AG. (2005). Analisis Kebijakan Publik, Yogyakarta : Pustaka Pelajar.

Sugiyono.(2013). Metode Penelitian 
Pendidikan, Bandung : Alfabeta.

Widodo, Joko.(2008). Analisis

Kebijakan Publik, Malang :

Bayumedia.
Winarno, Budi. (2002). Teori dan

Proses Kebijakan Publik, Yogyakarta: Media Pressindo.

Winarno, Budi.2009. Kebijakan Publik, Jakarta : CAPS. 